Historic, archived document

Do not assume content reflects current scientific knowledge, policies, or practices. 

Northeastern Forest
Experiment Station

Research

Note NE-311

1982

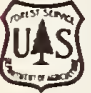

David A. Gansner Owen W. Herrick

\begin{abstract}
Presents a method for estimating the potential impact of gypsy moth attacks on forest-stand value. Robust regression analysis is used to develop an equation for predicting the rate of change in timber value from easy-to-measure key characteristics of stand condition. ODC 453-145.7 x 18.77 Lymantria dispar L. :624.4
\end{abstract}

Recent studies in Pennsylvania show that while most forest stands come through a gypsy moth outbreak with little or no loss in timber value, a few suffer heavy damage. Knowing how much value loss to expect for a stand and which stands will suffer most would be advantageous to planners of costeffective control programs. In an effort to solve that problem, we have developed a model for estimating the potential hazard of impending gypsy moth attacks - a simple equation that uses easy-to-measure key characteristics of stand condition to predict the rate of change in timber value for stands that go through an outbreak.

\section{Collecting the Data}

Changes in timber value over an 8-year period were measured on 131 plots in Pike and Monroe Counties, Pennsylvania. This area was on the frontier of gypsy moth infestations in the early 1970's. The $1 / 10$-acre plots were established in 1971 at random in newly infested woodlands. Severity and frequency of gypsy moth attacks varied from plot to plot. In general, the study area had moderate to heavy defolia- tion from 1971 through 1973. Insect populations collapsed in 1974 and 1975 , built up again to some extent in 1976 through 1978, and virtually disappeared in 1979.

In the fall of 1979 the plots were revisited to record changes in timber value occurring since 1971. We began the study with more than 150 plots. But those that were cut for timber and development or sprayed to control gypsy moth during the study period were dropped from the analysis. So, 131 relatively undisturbed plots remained for measuring the effect of gypsy moth on stand value.

Conversion standards developed by Mendel and his co-workers (1976) were used to estimate timber value. These value standards account for average regional conversion costs and incorporate species, dbh, butt-log grade, and merchantable height for each tree. Because our intent was to concentrate on impacts of the pest, we held the value standards constant over the study period. We thus avoided effects of inflation and changes in timber prices that oc. curred during the period.

\section{Fitting the Model}

Robust regression, a weighted regression technique, was used to construct the model. Robust regression minimizes the influence of data points with large residual errors, that is, large differences between predicted and actual values of the dependent variable. The technique sacrifices the fit of suspect or "outlier" data for a better fit of the remaining more important information. Robust regression usually results in equations that are better predictors (see Andrews, 1974). In this application, the weight used was 1.5 times the median of the absolute values of the residual errors.

\section{The Dependent Variable}

The rate of change in timber value expressed as a compound interest percent was chosen for anal. ysis as the dependent or predicted variable. Timber value incorporates a number of important attributes of stand condition such as species composition, tree size, and timber quality. Compound rates of change account for both the amount of change and the time involved in the change. So compound rates of change in timber value provide useful information for assessing the impact of gypsy moth on forest stands and for gauging the relative worth of control projects. For the 131 plots included in this study, changes in timber value ranged from $-\$ 375$ to $+\$ 370$ and averaged $+\$ 13$ per acre ( +12 percent) over the 8 -year study. When expressed as compound rates of interest, changes in value ranged from -6.8 to +9.1 and averaged +1.3 percent. 


\section{Independent Variables}

Several variables of forest stand condition thought to be good candidates for predicting changes in timber value associated with gypsy moth outbreaks were selected for analysis as independent variables. These variables are measures of:

Timber stand size composition

Average tree diameter

Timber stocking

Timber stand age

Species composition

Crown position

Crown condition

Site index

Land capability

Elevation

Aspect

Slope

Position on slope

The choice of these variables was based primarily on findings of Kegg (1971), Campbell and Sloan (1977), Houston and Valentine (1977), Gansner and co-workers (1978), and Herrick and co-workers (1979).

These variables were then screened with the help of correlation and stagewise regression analysis to select the best ones for the model. We were looking for predictors that (1) are easy to measure, (2) explain large amounts of variance in the dependent variable, and (3) are not highly correlated with one another. Three were selected:

- Basal area per acre in tree species that gypsy moth tends to avoid. ${ }^{1}$

- Percent of basal area in trees 3.0 to 4.9 inches $\mathrm{dbh}$.

${ }^{1}$ Such as yellow-poplar, ash, black locust, and sycamore.
- Percent of basal area in trees with poor crowns. ${ }^{2}$

\section{Results}

Robust regression analysis gave us a simple equation for predicting the rate of change in timber value for infested stands:

$$
\begin{gathered}
R=1.143+0.065(\mathrm{BSA})+ \\
0.082(\mathrm{PBS})-0.107(\mathrm{PBP})
\end{gathered}
$$

where

$$
\begin{aligned}
& R= \text { Compound rate of change } \\
& \text { in timber value }
\end{aligned}
$$

$\mathrm{BSA}=$ Basal area per acre in tree species that gypsy moth tends to avoid
PBS = Percent of stand basal area in trees 3.0 to 4.9 inches $\mathrm{dbh}$
PBP $=$ Percent of stand basal area in trees with poor crowns.

Only three of many elements of stand condition analyzed as independent variables are included in this equation. Including them makes especially good sense because (1) stands with greater stocking in species avoided by gypsy moth are usually attacked less severely and thus tend to have lower mortality rates and higher value growth rates; (2) trees in the 3.0- to 4.9-inch dbh class have little or no value for timber products, but those that survive gypsy moth attacks soon grow into merchantable size and thus have high value growth rates; (3) trees with poor crowns have lower vigor, are more likely to die after defoliation, and have lower (often negative) value growth rates.

\footnotetext{
${ }^{2}$ Crowns were classed as poor when 50 percent or more of the branches were dead (allowances permitted for non-selfpruning species); when foliage density, size, or coloration was of subnormal quality, or when epicormic sprouting was heavy.
}

\section{Implications for Management}

The model has limitations. It has not been field tested, and we do not know how well it will work on a new frontier of infestation. Plans have been made to test it. Also, it takes no account of important nontimber impacts on esthetic quality or the nuisance of caterpillars in recreation areas and back yards.

Despite its problems, the model and others like it seem to offer useful tools for decisionmaking. Especially where timber value is important. Consider these two typical stands:

\section{Stand \#1 Stand \#2}

Basal area per acre in species avoided $\left(\mathrm{ft}^{2}{ }^{2}\right)$

Percent of basal area in trees 3.0 to 4.9 inches dbh

Percent of basal

area in trees

with poor

crowns

65

According to our model, if Stand \#1 suffered a gypsy moth outbreak untreated, we could expect a compound rate of change in timber value of about -5 percent over the next 8 years or so. Whereas, the rate of change for Stand \#2 would be +5 percent. With this kind of information, choices of how to manage for the gypsy moth can be made more objectively.

\section{Acknowledgments}

Our sincere thanks to personnel of Forest Pest Management staff, Northeastern Area State and Private Forestry, USDA Forest Service, for support in collecting and analyzing data. 


\section{References}

Andrews, D. F. A robust method for multiple linear regression. Technometrics 16(4):523-531; 1974.

Campbell, Robert W.; Sloan, Ronald $J$. Forest stand responses to defoliation by the gypsy moth. For. Sci. Monogr. 19:1-34; 1977.

Gansner, David A.; Herrick, Owen W.; White, William B. Economic analysis of the gypsy moth in the Northeast. IV. Forest stand hazard ratings for gypsy moth. 1978; USDA For. Serv. Res. Pap. NE-410. 3 p.

Herrick, Owen W.; Gansner, David A.; DeBald, Paul S. Predicting forest stand losses from the gypsy moth; an application of automatic interaction detection (AID). J. For. 77(2):91-94; 1979.

Houston, David R.; Valentine, Harry $T$. Comparing and predicting forest stand susceptibility to gypsy moth. Can. J. For. Res. 8(3):447-461; 1977.

Kegg, John D. The impact of the gypsy moth: Repeated defoliation of oak in New Jersey. J. For. 69(12):852-854; 1971.

Mendel, Joseph J.; DeBald, Paul S.; Dale, Martin E. Tree value conversion standards for hardwood sawtimber. SETs: Stand evaluation tools 2. 1976; USDA For. Serv. Res. Pap. NE-337. 74 p.

David A. Gansner is a research work unit leader and Owen W. Herrick is a research forester at the Northeastern Forest Experiment Station, Broomall, PA.

Manuscript received for publication 27 October 1981 
